\title{
Through the Lenses of the Alumni: Enhancing Quality in the Zimbabwe Open University
}

\author{
Prof. Mupa Paul \\ Quality Assurance Co-ordinator: Zimbabwe Open University \\ E-mail:mupapaul@gmail.com \\ Professor Chrispen Chiome
}

Zimbabwe Open University: Associate Research Professor;

E-mail: chrischiom@yahoo.ca

\section{Prof. Chabaya Raphinos Alexander}

Masvingo Regional Campus Director

Email: raphinoschabaya@gmail.com

Prof. Chabaya Owence

University of Limpopo

E-mail:chabayaowence@gmail.com/ Owence.chabaya@ul.ac.za

\section{Doi:10.5901/mjss.2014.v5n11p167}

\section{Abstract}

\begin{abstract}
Universities lack quality provision of services as a result of out locking out some very important stakeholders like alumni. Alumni are the friends of the universities and their involvement in the affairs of universities is a blessing. This research analysed alumni views on ways of enhancing quality in the Zimbabwe Open University. The research was based on the pragmatist philosophy which leads to the mixed methodology. It was a case study of members of the alumni selected through convenience sampling. The study employed mixed methods research because both closed and open ended questionnaires were used as data gathering instrument. For data analysis, the constant comparative was used. The research found out that the alumni expect the university to establish an alumni directorate that will network with their members who will be involved in critiquing the processes of the university and fundraise for it. They also expected the university to establish a centre for teaching excellence, appoint a research champion for the university and provide critical resources as ways that contribute towards quality. The study among other things recommended the full involvement of alumni through a directorate and the establishment of a centre for excellence to promote quality pedagogical practices in the university.
\end{abstract}

Keywords: alumni, quality, open and distance learning, teaching excellence and pedagogy

\section{Background}

On the $11^{\text {th }}$ anniversary of the Zimbabwe Open University, alumni made several contributions. A survey was done to get their views on how to continuously improve the standards of the university at the Masvingo Regional Campus. Alumni for the Zimbabwe Open University were gathered in large numbers to celebrate the growth of their university. Products of a university want to be associated with their institution as was seen on the anniversary day. Alumni influence is critical to institutions because professional and personal connections held by graduates can open doors to the legislature, governor's office, corporations, foundations, and other major gift prospects (Weerts and Ronca, 2007). It is therefore argued that there is need for universities to reframe the mission of alumni in order to make the graduates contribute towards quality issues of their former institutions. Universities need not look at alumni as their banks but as a coaching network. Alumni are ambassadors who should offer personal real world insights from a graduate perspective. Such insights become useful to the university leadership in improving the quality of programmes and services to the students on track. Surveying alumni assesses the knowledge and skills developed in their college education and those developments relate to their skills and leadership in the workplace (Weerts and Ronca, 2007). According to Hoey and Gardner, (1999) alumni render quality judgements as they evaluate their performances in the workplace, scrutinise faculty 
productivity on campus, and critique the content and character of undergraduate and graduate curriculum in the universities". Alumni give insight to university leadership on areas that need improvement in order to provide quality services to forthcoming students (Baird, 1996). Universities should see the alumni as a talent pool.

Alumni play many roles in relation to the institutions of higher education from which they graduated. Colleges and universities actively engage their alumni in some roles. In other roles, alumni have an effect on their alma maters irrespective of immediate institutional involvement (Pettit and Litten, 2003; Weerts, Cabrera and Sanford, 2010). The value that alumni can add to the successful functioning of an institution has been generally underestimated by the higher education sector (Godfrey and Godfrey, 1999). Beyond the positive role played by currently registered students, former students or alumni of an institution also fulfil an immensely positive role in higher education transformation. Contributions from alumni are the single most important source of voluntary support in higher education. It is no surprise then that universities strive to gain loyalty, interest and counsel from their alumni. Some people think that if you win the alumni, and the dollars will follow. There is wide spread literature to the effect that alumni perceptions are important to the assessment of academic programmes in higher education (Davidson-Shiver, Inpornijivit and Sellers, 2004; Heywood, 2000; Kraus, 2007). An alumni assessment can provide valuable information to university administration about academic programmes, quality improvement and delivery modes.

Park (1994) identifies alumni as a relevant population for assessment, because they can share insight that has not been realised by current students because of their objective distance from the programme. Alumni can contribute to the assessment of student outcomes, programmes, goals, policy, management and instruction within programmes (Knapper and Cropley, 2000). Empirical studies by Stone (2001) acknowledge that alumni as a stakeholder group can, due to their contributions (whether financially or socially) increase the credibility and longevity of their alma mater. The potential for alumni to conduct fundraising, their right to institutional Council representation, their ability to build a skills- and knowledge sharing network and their potential for actualising lifelong learning responsibilities could make a meaningful difference in the way an institution is perceived by prospective and existing internal and external stakeholders.

It is argued that that alumni associations and clubs develop programmes and services that can both advance the university's goals and objectives and encourage alumni support. Some universities have a full time director of alumni. The function of the director of alumni relations is to see that alumni are appreciated rather than exploited, cultivated rather than coerced, frankly informed rather than party timed and above all interested in and organised for more than money making. Alumni are the clients of the higher education. According to Melchioni (1988) the purpose of such people is to identify broad educational, psychological and sociological changes or to assess the impact higher education has on its consumers. When surveying alumni, they are providing "graduates" assessment of what they have learned, how well they have learned, how well they have been able to apply their knowledge into practise and the extent to which their programme enabled them to achieve professional competence (Delaney, 1997).

It is argued that alumni help to determine if education is serving its purpose. Moden and Williford (1998) note that it is strategic for institutions of higher learning to establish and maintain good relations with its alumni by involving them in decision-making, network-building and development processes towards the overall advancement of that institution. In order to do so, however, it is pivotal that the institution have established open and direct communication channels with alumni (Legoabe, 2011).

Steveson, Walleri and Japely (1985) discuss the importance of following up with former students. They talk about the impacts of assessing alumni, which can help in programme reviews and improvements and developing marketing for programmes. Most universities note that alumni are their pride and are role models. The alumni can embark on a fundraising campaign to raise necessary donor funds for the refurbishment of laboratories.

According to Baade and Sundberg (1996) former students act more out of loyalty towards the institution and out of concern for its survival. Because of the high alumni membership profiles of universities, which indicate social standing, income and corporate status, these alumni networks could provide the institutions with valuable financial, intellectual and human resources that could lead to differentiation within the overall business strategy of the institution. Such strategic networking and utilisation of resources emanating from an alumni network results in constructive social, political and economical positioning of an institution and the realisation of its strategic objectives in a much more cost- and time effective manner (Barnard Rensleigh and Niemann, 2006).

According to Hung (2003) an efficient alumni network with external stakeholders assists the institution in positioning itself strategically in an often hostile external environment, as these stakeholders could act as brand ambassadors for the institution. In many ways, alumni are the real measure of a tertiary institution's brand. Fundamentally, an institution's reputation and prominence rest on the manifestations of its graduates: their knowledge and competence, successes, contributions, position and stature. These alumni reflect daily in numerous situations, places and interactions the core identity and values of the University. 


\section{Statement of the Problem}

Many researches have been undertaken in the Zimbabwe Open University on matters to do with students and tutors. Little is yet known about the role of the alumni as regards the Zimbabwe Open University graduates. This study seeks to contribute to the body of knowledge by looking at the objective contributions of the graduates of the university. This research seeks to fill this void.

\section{Research Questions}

This study generated the following research questions:

1. How can ZOU involve alumni to attain quality?

2. Which areas need improvement in ZOU in order for it to achieve quality?

3. What are the factors influencing the achievement of quality in ZOU?

4. How best can ZOU improve student retention?

\section{Research Design}

Research design is regarded as a blue print of research which deals with what questions to study, what data to collect and how the results are analysed. The researchers employed the case study design. Babbie (1997) says case studies are set in temporal, geographical, organisational, institutional and other contexts that enable boundaries to be drawn around the case. The researchers chose this design as it looked at the case of ODL alumni of the Zimbabwe Open University. Mixed methods in social science research are defined as a technique that mixes or combines quantitative and qualitative research techniques, methods, approaches, concepts or language into a single study (Johnson and Onwuegbuzie, 2004, p. 17). This was a qualitative dominant mixed methods research. Patton (1990) highlights that qualitative methods consist of open ended questions. Robbins and Coulter (2005) highlight that using surveys on a regular basis provides managers with valuable feedback on how students and other stakeholders perceive their learning conditions. The use of surveys alerts managers to potential problems and student intentions early so that action can be taken to prevent recurrent of the challenges.

\section{Sample and Sampling Procedure}

The target population for this study was all alumni members who were present at the Masvingo regional campus on the ZOU day when ZOU was launching its on line programme on its eleventh anniversary. The participants were sampled using the purposive sampling technique. A total of 70 participants were sampled conveniently from the population that had come for the commemoration of the eleventh anniversary. Patton (1990) argues that the logic and power of purposeful sampling lies in selecting information rich cases for study in - depth. Purposeful sampling was done at random and was inclusive of sampling by case (researchers selected at random certain cases that would in all probability yield the information that is required. The information rich participants who are selected were knowledgeable and informative about the phenomena the researcher is investigating. The participants were willing to talk. This research focused on alumni because they had information about the university since they are former students. The open ended questionnaire was given to alumni who had time and were willing to complete open ended questions (Flick, Kardoff and Steinke, I (2004). It is argued that quality assurance procedures for internal institutional audit include surveys of key stakeholders such as students, graduates and employers. Hence the study used alumni survey to improve ZOU standards. All the alumni had studied with ZOU in at least a diploma or degree in any programme.

\section{Instrument}

The instruments used in this study were closed and open ended questionnaire to which the respondents answered in full. Self completion was selected as the most appropriate tool because this was a small scale research where knowledge needed was controlled by the research questions to afford precision and clarity. The open form questionnaire was used. It is argued that rather than forcing respondents to choose between rigidly limited responses the open form questionnaires permits them to answer freely and fully in their own words and their own frame of reference. This method also gives the subjects an opportunity to reveal their motives or attitudes and to specify the background or provisional conditions upon which their answers are based. 


\section{Procedure}

The open-ended questionnaire was administered to alumni members at the start of the celebrations. Greenwood and Gaunt (1994) highlight that questionnaires can be given out at open days. Permission to administer the questionnaire was sought from the regional director of the campus. All the participants willingly participated in the research as their consent was sought first.

\section{Data Analysis}

Data collected for this study was analysed using the consent analysis techniques. The themes were derived from the key research questions.

\section{Findings and Discussion}

This section presents findings of the ways of enhancing quality in ZOU through the lenses of the alumni. These ideas are presented in themes.

\section{Engaging Alumni}

The alumni members in this study thought the best way forward is to engage them in critiquing processes as captured by this extract:

You need to engage former graduates so that they will critique programmes, processes, curricular and knowledge and skills. All the institution's graduates need to internalise the motto and the ethos of their alma mater. All former students are ready to market, promote and become the custodians of the university's legacy.

Engaging alumni was seen as a way of enhancing quality because these members will take it upon themselves to critique the processes in the Zimbabwe Open University.

\section{Directorate for Alumni}

The respondents in this study pointed out that ZOU need to have a directorate that specialises on alumni affairs. The following quote appears to point to this need.

\section{Appoint a full time directorate for alumni with the mandate to engage former students in all matters to do with upholding} the integrity of the university. The directorate will enable networking opportunities for alumni members.

It is interesting to note that the respondents in this study have a heart for the university. They want a full time directorate to address their needs and work towards sprucing the image of the university and at the same time promote networking.

\section{Establish E-Learning Centres in Districts}

Respondents were of the opinion that e-learning centres are sources of excellence in an open and distance teaching university. In this regard, they highlighted the following views as the importance of the e - learning facility:

E-learning widens students' horizon of knowledge as students can assess volumes of information at the click of the button. However, these must be nearer to the students. Establish e-learning centres in districts because they put the university on the map and at the same time links students with the rest of the world. In this way, it promotes quality learning and improves research.

These findings seem to indicate that the introduction of the ZOU e-learning facility is a positive move towards improved learning conditions for students. The alumni highly appreciate the facility. Jing (2005) says in Asia ODL institutions have adopted ICT to support supplementary modes of instruction and more importantly as a means of improving students' services and providing interactions and to widen access to education, satisfy continuing educational 
needs of adults, expand trained workforce and / or train teachers to improve the quality of schooling. It remained necessary to implement e-learning as a viable approach for reaching underserved learners living in the country's provinces. There major benefits of e-learning are that: e-learning lowers costs, enhances business responsiveness, messages are consistent or customized, is need based, content is more timely and dependable, learning is anywhere, anytime, no user "ramp up " time, universality, builds community's capability, leverages the corporate investment in the web, and provides an increasing valuable customer service.

\section{Harnessing the Competitive Advantage of ZOU}

The alumni members in this study thought that an important way of ensuring quality is through utilisation of the competitive advantage of an open and distance learning university. Alumni raised the following issues on the competitive advantage of ZOU:

\footnotetext{
Studying in the comfort of home, family support and no interruption at work places using user friendly modules. Reaching out to the workforce through distance learning and catering for all age groups. In the case of ZOU, it is strategically positioned in all the ten provinces of the country
}

The above findings seem to indicate that ZOU has a competitive advantage over convectional universities. Workers would prefer to obtain degrees through distance education as it gives them chance to work, learn and earn. Robbins and Coulter (2005) argue that competitive advantage is what sets an organisation apart, that is, its distinct advantage. That distinct edge comes from the organisation's core competencies which might be in the form of organisational capabilities - the organisation does something that others cannot do or does it better than others can do it. Significantly, the Zimbabwe Open University advances human welfare by using a vehicle that is different from other national universities or enterprises. It uses efficient and effective, stakeholder friendly and more specifically, student friendly, service machinery.

\section{Use of User Friendly Modules}

The alumni in this study were of the view that ZOU need to provide user friendly modules. Some of the related statements are:

The module sets the university apart from other universities. It must be used to enhance quality. User friendly modules with quality content are important for enhancing quality in an open and distance teaching university.

The idea of user friendly modules used by ZOU sets it apart from convectional universities. Students can use the modules anywhere, anytime. What is important is to give customers what they want quick, convenient and quality service. Distance learning is flexible and allows one to continue working and at the same time being able to put into practise what has been learnt. It is argued in educational theory and practice that the individual who develops his abilities while producing expands them as well. Taking cognisance of the economic times that we are in, it makes economic sense to work and study at the same time. It is not enough for ZOU to create a competitive advantage, it must be able to sustain it. That is, a sustainable competitive advantage enables the organisation to keep its edge despite competitors action or evolutionary changes. Quality is considered as the cornerstone for distance education for continuous improvement.

\section{Involving Alumni to Improve Funding for Quality}

On the issue of how the university can involve alumni to improve its standards, the following responses were generated: : engage alumni in sourcing for funds and resources like textbooks, computers etc.

Engaging alumni as part time tutors. Forming viable alumni committees and association. Best students to be involved in conducting tutorials freely.

Making consultation meetings with alumni. Making a record of all alumni and encouraging them to make contributions.

Engage alumni in fundraising, invigilation and exam processing.

Using alumni to write articles and publishing these in university newsletters.

Alumni are not only future donors of an institution but are also continuing learners and are as such, an institution's 
lifelong customers. Past students are also vital future corporate partners, student recruiters and employers, advocates, mentors and career advisers. Nielsen (2001) states that alumni provide a way for organisations to get value from people even after they have left the organisation. The alumni of an institution can make a priceless contribution to the macro management of the university, since these representatives would be the mouthpiece of a crucial interest group of the institution, namely its alumni (Legoabe, 2011).

Alumni are meant to network, reconnect and stay engaged. The alumni community has various critical skills that it can and should use to contribute to change for the better the abject living conditions that define those who populate the vast landmass called Africa. Alumni can be used to ensure that Africans achieve the vision that we must volunteer our time to do good. Alumni are a body that must lead in areas of research.

\title{
16. Establish Centre for Teaching Excellence
}

Alumni were of the opinion that a teaching and learning centre whose key function is promote quality pedagogical practices was proposed in this study. The following responses bear testimony:

The majority of the academic staff needs constant re-sharpening of their pedagogical skills. This can be done if the university has a teaching centre earmarked for that purpose.

The above findings seem to shed light on areas that need improvement in ZOU. Since ZOU uses part time lecturers, it has to consider conducting workshops with them for quality assurance purposes and continuous improvement. Aside from social and financial interaction, strategic interaction is another key benefit accruing to higher education institutions from alumni constituents. According to Nielsen (2001) alumni strategic interaction includes institutional council representation and community development through responsible citizenship.

There is need for revitalisation within universities by involving alumni in their day to day activities. Leaders must engage in meaningful self reflection to reframe their perspectives. Such processes of self reflection permits the leader to engage others in the kind of quality thinking that promotes a paradigm shift, creating an atmosphere of regeneration. In any educational institution, the library is the heart and source of information. Zimbabwe Open University has the ability to expand its library facilities in order to meet the needs of students in the different faculties. Kefalas, Retalis, Stametis and Theodoros (2003) highlight that a quality assurance system should be done to the courses and degrees offered and the learning content, the staff, technology, learning methods, services and the organisational and managerial structure. Alumni are a source of quality assurance systems that could help to improve in the various areas.

\section{Market Driven Programmes}

Programmes offered by ZOU had much to do with enhancing quality. The following views were raised on the programmes offered by ZOU.

\begin{abstract}
Important, effective and competitive vibrant and market development oriented programmes will put the university in the right footing for quality. Programmes that are challenging, relevant, practical to the Zimbabwean situation and marketable can enhance quality.
\end{abstract}

The findings seem to indicate that alumni are noticing a change in their economic, social, and professional positions in life as a result of attaining a degree with the ZOU. The findings indicate that ZOU offers useful programmes to students, society and for the development of human capital in Zimbabwe. It is argued that the object of philosophy and teaching is not only to make students acquire knowledge but also wisdom, which is knowledge in action, knowledge applied to real life in the real world. The alumni seem to indicate that there is need to include certain aspects in programmes offered. They indicate that the idea of arts and culture is lacking and hence has to be included. Karl Marx argues that man, cannot and should not passively go with the flow, moving by inertia, without thinking about where he is headed, about whether or not the inertia is positive and whether or not at all the traditions are good and all thee behests correct. He should constantly analyse, weigh, contemplate and check what is going on.

In line with Marx's thinking, universities should involve the alumni in checking what is going on in their institutions, whether or not they are heading to a success or failure. Alumni are responsible for analysing and checking programmes offered by the former university, which in this case is ZOU. The university has to consider making necessary changes and improvements in the areas raised. Kefalas, Retalis, Stametis and Theodoros (2003) highlight that quality assurance system should also be done at course design level. 


\section{Resources Needed for Quality}

The alumni pointed out that availability of resources is an important aspect for quality. Some of those prominent are:

- Availability of resources and quality modules.

- Lecturers who are competent, committed and dedicated to ODL practices.

- Effective coordination by the Regional Director culminating in good relationship with wider public and the corporate world and other institutions of learning.

- Leadership that utilises talented, gifted and mature academics in all spheres of ZOU with wide research capacity among tutors.

- Friendly lecturers who assist students anytime, anywhere, even at the bus stops.

Alumni responses show that ZOU managers have empowered all their employees and hence are motivated to work very hard for the university. The findings show that the lecturers, regional director and administrative staff are patriotic to the university and have students' welfare at heart. Empowerment is a process of energizing the grassroots. The organisation provides power tools to its employees which are information (data, technical knowledge, intelligence, expertise) resources (funds, materials, space, time) and support (endorsement, backing approval, legitimacy to invest into action. Dewey (1964) suggests that the effective educational leader promotes high quality educational experiences that help students become autonomous and intelligent in guiding their own future educational experiences.

\section{Employing Strategies for Student Retention}

Student retention was seen as a critical measure of quality. The alumni in this study pointed to strategies they thought will improve student retention. The following statements were given:

- Introduce cadetship / grants like other state universities.

- Establish a follow up scheme on drop outs and students legging behind.

- Involve students in decision making that has to do with fees increases.

- Introduce an easy fees payment plan.

The findings seem to indicate that students have economic hardships and need financial support services. The university management should lobby the issue of cadetship and provision of grants and loans with the government. Although an educated workforce is more important than ever, many colleges and universities now realise that retention is a major problem as it is dropping. Student persistence in colleges is chronically low. The trends seem to have changed. Student enrolment used to be very high even in the Zimbabwe Open University. At its pick in 2004 student enrolment in ZOU rose up to about twenty thousand students. Alumni can assist in student enrolment by speaking well about their former university because the word of mouth is very important than written material. ODL universities can take advantage of their alumni who are abroad and such connectedness can be a link to recruit students. Alumni give their former institutions lenses to see ahead and prepare for the future (Harvey and Huber, 2012). It is argued that universities with poorly maintained alumni databases or with small alumni numbers cannot expect to wield high student enrolment from a position of strength (Worthington and Horne, 1995).

It is noted with concern that tertiary education has become impossibly expensive. Dr Sikhanyiso Ndlovhu in the Sunday Mail of June 6, 2010 highlighted that the government should increase the number of students who benefit from the cadetship programme. He argued that the cost of tertiary education has gone beyond the reach of many. The ultimate result is that some very intelligent students will not be able to access tertiary education. He added that students under the cadetship programme have to be increased and that the government should consider reintroducing the students' loans because they are essential in the prevailing environment. Dr Ndlovu reiterated for the need for finance schemes for students which are diversified. The university leadership has to lobby the issue with the government so that even students studying through the ZOU are also considered for cadetship, grants and other diverse finance schemes because they are in the same economic environment.

\section{Conclusions}

From the above findings, this research concludes that good, dedicated and committed alumni are an asset for any university. They are the builders of the university. The more sincere and honest alumni members we have, the brighter the future of a university. In this regard, the alumni proposed that to enhance quality, there is need to establish a viable association that will mobilise and improve the level of engagement between the institution and its alumni. The aim is to 
advance the vision and mission of the University and spruce its image and reputation. Inn this direction, the university need to have a full-time alumni directorate tasked with engaging former students who will critique the operations and processes of the university. It is also imperative to unleash sustainable competitive advantage that enables the organisation to keep its edge despite competitors' action. They claim ZOU has competitive advantage over conventional universities. What sets an organisation apart, that is, is ZOU's distinct competitive advantage. That distinct edge comes from the organisation's core competencies which might be in the form of organisational capabilities. These will enhance quality. Student persistency is chronically low calling for the need to find strategies of student retention in the university.

\section{Recommendations}

From the above conclusions, this research gave the following recommendations:

- Open Universities need to prepare today's students for tomorrow's challenges harnessing ideas from former students because alumni are key stakeholders.

- A full-time alumni directorate whose mandate is to link alumni from all over the world, increase networking and empower the university so that it reaches its full potential through alumni suggestions.

\section{References}

Baade, R. A., Sundberg, J. O. (1996). What determine alumni generosity? Economics of Education Edition 15 Vol 1. Pages $74-81$.

Babbie, E (1997) The practice of social research. CA. New York, Wadsworth.

Baird, L. (1996). Documenting student outcomes in graduate and professional programs. New Directions for Institutional Research 92: 77-87.

Barnard, Z., Rensleigh, C., Niemann, I. (2006). Investigating ICT's for Relationship Marketing targeting alumni of the University of Johannesburg. International Journal of Technology, Knowledge and Society.Edition 1, Vol 6. Pages $103-114$.

Davidson-Shiver, G., Inpornijivit, K., Sellers, K. (2004). Using alumni and students databases or program evaluation and planning. College Student Journal 38 (4) 510.

Delaney, A. (1997). Quality assessment of professional degree programs. Research in Higher Education. 38 92) 241-264.

Dewey, J. (1964). The Child and the Curriculum. John Dewey on Education: Selection Writing. New York, 1902.

Flick, U.; Kardoff, E and Steinke, I (2004). A comparison to qualitative research. London. Sage.

Godfrey, J. M., Godfrey, P. J. (1999). Benchmarking quality management: How does it apply to the university alumni office? Benchmarking, An International Journal. 6 (1) 40 - 59.

Greenwood, M.S. and Gaunt, H. J (1994). Total Quality Management for Schools. London, Cassell.

Harvey, M. and Huber, E. (2012). Expanding the Horizons of Professional Learning: A Foundations Alumni Network. Asian Social Science; Vol. 8, No. 14; pp. 21-27.

Heywood, J. (2000). Assessment in higher education. Student learning, Teaching, programmes, and institutions. London: Jessica Kingsley Publishers.

Hoey, J., Gardner, D. (1999) Using surveys of alumni and their employers to improve an institution. New Directions for Institutional Research 101: 43-59.

Hung, S. (2003). Mobilizing networks to achieve strategic difference. Long Range Planning. Edition 35 Vol 6.

Jing, I. S (2005). Quality assurance survey of mega universities: Life long learning and distance higher education. Vancouver. Commonwealth of learning and Paris: UNESCO.

Johnson, R. B. and Onwuegbuzie, A. J. (2004). Mixed Methods Research: A Paradigm Whose Time Has Come, Educational Researcher, 33 (7) 14-26.

Kefalas, P; Retalis, S; Stametis, D and Theodoros, K (2003) Quality Assurance Procedures and e-ODL. International Conference on Network. Universities and e-Learning. Valencia -Spain.

Knapper, C., and Cropley, A. (2000). Lifelong learning in higher education: London: Koganage Limited.

Kraus, J. M. (2007). Alumni Assessment: Providing Insight to University Leadership Vol. 5, Issue. 1. ISSN pp $1523-7812$.

Legoabe, R. (2011) The role of Students and Alumni in Higher Education Transformation. Discussion Paper prepared for the AntiRacism Network in Higher Education (ARNHE) Collogium, University of Johannesburg, 27th May 2011. Higher Education Transformation Network.

Melchioni, G. (1988). Alumni research: An introduction. New Directions for Institutional Research 60: 5-11

Moden, G., and Williford, M. (1998), Applying alumni research to decision making. New Directions for Institutional Research 60: 67-76.

Nielsen, R. (2001). Keeping them in the fold: Corporations join campuses in the alumni relations business. Classic Current. CASE: Washington DC.

Park, L. (1994). Good accounting skills. What more does a successful account need? Journal of Education for Business 69 (4) 231-234.

Patton, M. Q. (1990) Qualitative evaluation and research methods. Newbury Park, CA. Sage.

Pettit, J. and Litten, L. H. (2003) A new era of alumni research. New directions for institutional research No. 101 Jossey-Bass Publishers.

Rice, R., Stewart, L. and Hujber, M. (2000) Extending the domain instructional effectiveness, assessment in students evaluations of 
communication course. Communication Education 49 93) 253-266.

Robbins, S.P and Coulter, M (2005) Management. New Delhi, Prentice-Hall of India.

Steveson, M., Walleri, R. and Japely, S. (1985) Designing follow-up studies of graduates and former students. New Directions for Institutional Research 47: 81-91.

Stone, W.E. (2001). Rethinking our Craft. Current Magazine. CASE Available www.case.org (Accessed 13 April 2011).

Weerts, D. J. and Ronca, J. M. (2007) Characteristics of Alumni Donors Who Volunteer at their Alma Mater. Springer Science+Business Media, LLC. pp. 275-292.

Weerts, D. J., Cabrera, A. F. and Sanford, T. (2010) Beyond Giving: Political Advocacy and Volunteer Behaviours of Public University Alumni. Res High Educ 51:346-365.

Worthington, S. and Horne, S. (1995) "Alumni affinity credit cards: making the relationship work", International Journal of Bank Marketing. 13 (5) $24-30$. 
